Hauck, APSA Deputy Director, and Jun Yin, Staff Associate, discussed the Association's history, organization, programs, and member services, giving special emphasis to how APSA serves the needs of civic educators in the United States. Sean Twombly, APSA's web page administrator, gave delegates guided tours of the web site and demonstrated how civic educators can use the site to link to needed resources.

At the conclusion of their visit, each delegate received a one-year membership and each delegation is sent a collection of APSA publications for use in their countries. Email addresses and contact persons for each international delegation can be found on the APSA web site (www.apsanet.org).

ICEE relies upon the participation and support of numerous international and national organizations, individuals, and institutions. In the United States, the organizations listed in the box participate in the program.

\section{Ad Hoc Committee on Technology Created}

Acting on a recommendation made by the Administrative Committee, APSA Council approved the formation of an ad hoc committee to assess the impact of recent developments in information technology on Association activities and to consider the opportunities presented by these developments.

Committee members-Pippa Norris of Harvard University, Chair; William J. Ball of The College of New Jersey, who is also the director of APSA's PROceedings project; Janet M. Box-Steffensmeier of Ohio State University; and Stephen Weatherford of the University of California, Santa Barbara-have been charged with determining how changes in information creation, storage, and transmission necessitate changes in and can improve APSA's activities. They will consider ways new technologies can be used to serve members and the public better, especially by expanding the Association's web site, making APSA publications available online, and continuing to develop
PROceedings. Special focuses for committee discussions will include how to structure and collect equitable fees for new services and how to replace revenues likely to be lost as more of the Association's publications are made web-accessible.

\section{JSTOR Adds Mirror Site in UK, Increases American Subscriber Base}

JSTOR, the Journal Storage

Project, which electronically archives and makes available online the full text of complete catalogs of selected journals, has added a mirror site in London and has increased its American subscriber base to include a consortium of small colleges in Appalachia and a number of historically black colleges and universities.

APSA is a flagship member of JSTOR, and the full catalog of American Political Science Review articles through 1994 became available to subscribers this spring.

The new UK mirror site gives access to most of the institutions of higher education in England, Scotland, Wales, and Northern Ireland. The expected success of the mirror site will serve as a springboard for establishing similar mirror sites in central and eastern Europe and southern Africa.

With the addition of the new American schools, JSTOR now has a North American subscriber base of 270 institutions.

\section{Encouraging the Brightest: The 1998 Ralph Bunche Summer Instifute}

\section{Jay Shaylor, University of Virginia}

Fifteen gifted African-American undergraduate students from colleges across the country attended the 12th annual Ralph Bunche Summer Institute at the University of Virginia this summer. Their mission: To learn more about graduate study in political science. Sponsored jointly by the department of government and foreign affairs at the University of Virginia and the American Political Science Association, the Bunche Institute is designed to introduce
International Civic Education Exchange Program Primary Sites

American Federation of Teachers

Education Foundation

American Political Science

Association

The Center for Civic Education

Russell Sage College, Council for Citizenship Education

Florida Law-Related Education Association

Indiana University, Social Studies Development Center

Mershon Center of The Ohio State University

Social Studies Program, Anchorage School District, AK

Social Studies Development Center of Indiana University

Additional Participants

U.S. Department of Education

Office of Educational Research and Improvement

National Inst. on Student Achievement, Curriculum, and Assessment

U.S. Information Agency

Bureau of Education and Cultural Affairs

Office of East Europe and NIS Affairs

ICEE-Secondary Sites

Arizona Center for Law-Related Education

Ashworth Middle School, Calhoun, GA

Center for Civic Education Through Law, Waterford, MI

Classroom Law Project, Portland, OR

Nevada Center for Law-Related Education

Kennesaw State University, Department of Political Science \& International Affairs

Maine South High School, Park Ridge, IL

Partners in Education, Inc., NV

School of Education, Boston

University

"We the People. .." The Citizen and the Constitution Program, IL

"We the People. .." Project, GA "We the People. .." Project, WA 


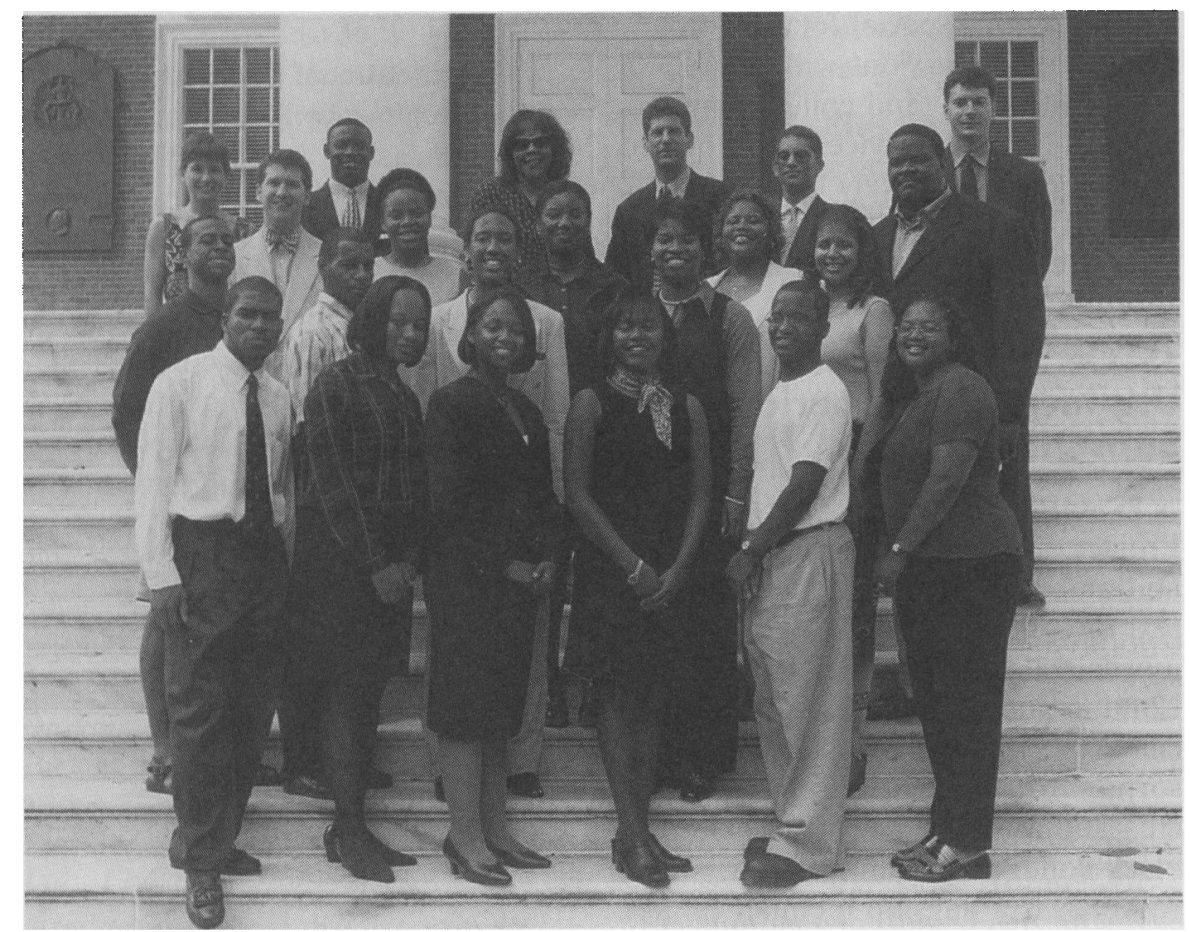

1998 Ralph Bunche Summer Institute participants and staff. Back Row (L-R): Stacy Nyikos (Graduate Assistant), Alan Kendrick (Graduate Assistant), Professor Paula D. McClain, Professor Steven Finkel (Director), Jeff Gulati (Graduate Assistant), Stan Humphries (Graduate Assistant. Third Row (L-R): Jay Shaylor (Assistant Director), Katrina Gamble, Elizabeth Green, Jabaria Willis, Marlow H. Colvin. Second Row (L-R): Ray Block, Arthdale Brown, Andra Gillespie, Kenyetta Alexander, Gloria Anglón. First Row (L-R): Melvin Rogers, Monique Lyle, Teah Williams, Doris Clark; James Gunn, and Aisha Raj.

African-American students to graduate school and to encourage their application to Ph.D. programs in political science. This year's class came from 15 schools as diverse as Smith College, Pepperdine University, and Central Arkansas State University.

While living on the grounds of UVA, the students spent five weeks in two graduate-level courses taught by distinguished members of the department's faculty and attended weekly lunches and dinners with visiting scholars from all over the U.S. The students toured Monticello, Thomas Jefferson's mountain home, and traveled to Washington, DC. Kaplan Testing Services administered a mock Graduate Record Examination and provided indepth analysis of their scores. And on June 26 , recruiters from 16 top graduate political science programs attempted to woo the students to their universities at a day-long recruitment fair.

Study at the Institute was intense but worthwhile. Monday through Thursday, the students met for four hours of either Professor Paula McClain's Race and American Politics course or a quantitative methods course, Political Analysis, taught by the Institute's director, Professor Steven Finkel. According to Ray Block, a Bunche Fellow from Howard University, the Institute was "the most worthwhile summer I have ever spent academically."

This year's program also proved one of the most successful in convincing students to apply to graduate programs in political science. According to Andra Gillespie, a fourthyear student at the University of Virginia, the collegiality of the program became a motivator for her to continue her study of political science. "At the end of one's college career," noted Gillespie, "one can begin to get lethargic about school. The Institute really challenged me to overcome that and got me excited about graduate school."

All of the students also reported marked improvement in their writing and research skills. "The Bunche Institute taught me how to think not only qualitatively and theoretically, but also how to back up my theories and qualitative observations with data and statistics," Jabaria Willis, a senior at Spring Hill College, said. Gloria Anglón of Providence College agreed. "The Institute has exposed me to areas of political science that I would not have seen in undergraduate school, plus I have met so many friends that will hopefully be fellow colleagues."

Because of its rigorous program, the Institute's scholars have seen great success. Yvette Alex-Assensoh. an assistant professor at Indiana University, Heather Dash, a graduate student at Emory University, anc Khalilah Brown, an entering graduate student at Ohio State are all Bunche alumnae. All three of them returned on June 26 to tell the students a little about how the Institute has impacted their lives. Many other alumni have attended and graduatec from top graduate and law program: over the past 12 years and three have been named assistant professors.

The Institute's namesake, Ralph Bunche, a 1934 Harvard University graduate, was the first African American to receive a doctorate in political science and the first to serv as the president of the American Political Science Association. In 1950 he also became the first African American to receive the Nobel Peace Prize.

The Institute has been held at the University of Virginia for the past three years. The program is supported financially by a grant from the National Science Foundation, the American Political Science Asso ciation, and by the University of Vir ginia.

\section{Spring Round of Minority Identification Project Big Success}

At the request of several core schools, a "Spring Round" has been added to the Minority ID Project. Many of the graduate schools have early-December application deadlines, and the Spring list better serves the needs of those schools. 